\title{
Pelvic Lymph Node
}

National Cancer Institute

\section{Source}

National Cancer Institute. Pelvic Lymph Node. NCI Thesaurus. Code C12363.

Any lymph node within the abdominal pelvic region. 